\title{
Seroprevalence of Brucella ovis-epididymitis, smooth-Brucella, leptospirosis, toxoplasmosis, and Maedi-Visna in sheep slaughtered in Minas Gerais State, Brazil
}

\author{
Soroprevalência de Brucella ovis, Brucella lisa, leptospirose, \\ toxoplasmose e Maedi-Visna em ovinos abatidos em Minas Gerais, Brasil
}

\author{
Elaine Maria Seles Dorneles ${ }^{1}$; Alessandro de Sá Guimarães ${ }^{1,2}$; Aurora Maria Guimarães Gouveia ${ }^{3}$; \\ Fernanda Morcatti Coura ${ }^{4}$; Filipe Borges do Carmo ${ }^{3}$; Rebeca Barbosa Pauletti ${ }^{3}$; Vasco Azevedo5; Walter Lilenbaum ${ }^{6}$; \\ Ricardo Wagner de Almeida Vitor ${ }^{5}$; Raymundo Rizaldo Pinheiro ${ }^{7}$; Amanda Carvalho Rosado Ferreira ${ }^{1}$; \\ Maurício Gautério Dasso ${ }^{8}$; Andrey Pereira Lage ${ }^{3}$; Marcos Bryan Heinemann ${ }^{9}$ (D) \\ ${ }^{1}$ Universidade Federal de Lavras, Departamento de Medicina Veterinária, Lavras - MG, Brazil \\ ${ }^{2}$ Empresa Brasileira de Pesquisa Agropecuária, Gado de Leite, Juiz de Fora - MG, Brazil \\ ${ }^{3}$ Universidade Federal de Minas Gerais, Escola de Veterinária, Departamento de Medicina Veterinária Preventiva, Belo Horizonte - MG, Brazil \\ ${ }^{4}$ Instituto Federal Minas Gerais, Departamento de Ciências Agrárias, Bambuí - MG, Brazil \\ ${ }^{5}$ Universidade Federal de Minas Gerais, Instituto de Ciências Biológicas, Belo Horizonte - MG, Brazil \\ ${ }^{6}$ Universidade Federal Fluminense, Instituto Biomédico, Centro de Ciências Médicas, Niterói - RJ, Brazil \\ ${ }^{7}$ Empresa Brasileira de Pesquisa Agropecuária, Caprinos e Ovinos, Sobral - CE, Brazil \\ ${ }^{8}$ Instituto de Pesquisas Veterinárias Desidério Finamor, Eldorado do Sul - RS, Brazil \\ ${ }^{9}$ Universidade de São Paulo, Faculdade de Medicina Veterinária e Zootecnia, Departamento de Medicina Veterinária Preventiva e \\ Saúde Animal, São Paulo - SP, Brazil
}

\begin{abstract}
The present study aimed to estimate the prevalence of antibodies against Brucella ovis-epididymitis, smooth-Brucella, leptospirosis, toxoplasmosis and Maedi-visna in sheep slaughtered in Minas Gerais, Brazil and to study their simultaneous occurrence, including caseous lymphadenitis, at sheep and flock levels. The study was conducted at a sheep slaughterhouse with Federal Inspection Service. Sera from 594 animals from 21 flocks were collected, in 2007. The agar gel immunodiffusion (AGID) was employed to detect anti-B. ovis and anti-Maedi Visna antibodies, whereas Rose Bengal (RB) and the 2-mercaptoethanol test (2ME) were used to test anti-smooth Brucella antibodies. For the detection of anti-Leptospira antibodies, sera were examined by microscopic agglutination test (MAT), while for the detection of IgG antibodies to Toxoplasma gondii ELISA was used. Prevalence of antibodies against smooth Brucella, B. ovis-epididimitis, Leptospira spp., toxoplasmosis and Maedi-Visna found in sheep from Minas Gerais was 0.00\%, 24.04\%, 25.96\%, 10.46\% and $3.08 \%$, respectively; whereas the seroprevalence in flocks was $0.00 \%, 80.95 \%, 90.48 \%, 71.43 \%$ and $23.81 \%$, respectively. Moreover, when data on antibodies anti-Corynebacterium pseudotuberculosis, previously obtained, were included, about $60 \%$ of the flocks showed animals that were exposed to four or more of the studied agents. However, only $25.47 \%$ of the sheep exhibited simultaneously antibodies against more than one pathogen. Thus, data from the present study on sheep slaughtered in Minas Gerais, Brazil, showed no antibodies to smooth-Brucella and a low frequency of antibodies anti-Maedi Visna lentivirus, and a high and widespread seroprevalence of B. ovis, Leptospira spp., and T. gondii among animals and flocks.
\end{abstract}

Keywords: Brucellosis. C. pseudotuberculosis. Leptospira spp. Maedi-Visna. T. gondii. Ovine. Serodiagnosis.

\section{RESUMO}

O presente estudo teve como objetivo estimar a prevalência de anticorpos contra Brucella ovis (epididimite ovina), Brucella lisa, leptospirose, toxoplasmose e Maedi-visna em ovinos abatidos em Minas Gerais, Brasil, e estudar sua ocorrência simultânea, incluindo linfadenite caseosa, nos ovinos e nos rebanhos. O estudo foi realizado em um abatedouro de ovinos com Serviço de Inspeção Federal. Soros de 594 animais de 21 rebanhos foram coletados, em 2007. A imunodifusão em gel de ágar (IDGA) foi empregada para detectar anticorpos anti-B. ovis e anticorpos anti-Maedi Visna, enquanto o teste do antígeno acidificado tamponado (AAT) e o teste de 2-mercaptoetanol (2ME) foram utilizados para testar anticorpos 
anti-Brucella lisa. Para a detecção de anticorpos anti-Leptospira, os soros foram examinados pelo teste de aglutinação microscópica (MAT), enquanto que para a detecção de anticorpos IgG para Toxoplasma gondii, foi usado o ELISA. A prevalência de anticorpos anti-Brucella lisa, B. ovis, Leptospira spp., toxoplasmose e Maedi-Visna encontrados em ovinos de Minas Gerais foi de 0,00\%,24,04\%, 25,96\%, 10,46\% e 3,08\%, respectivamente; enquanto a soroprevalência em rebanhos foi de $0,00 \%, 80,95 \%, 90,48 \%, 71,43 \%$ e $23,81 \%$, respectivamente. Além disso, quando dados de anticorpos anti-Corynebacterium pseudotuberculosis, previamente obtidos, foram incluídos, cerca de $60 \%$ dos rebanhos apresentaram animais expostos a quatro ou mais dos agentes estudados. No entanto, apenas $25,47 \%$ dos ovinos exibiram simultaneamente anticorpos contra mais de um patógeno. Assim, os dados do presente estudo sobre ovinos abatidos em Minas Gerais, Brasil, mostram que ausência de anticorpos anti-Brucella lisa e baixa frequência de anticorpos anti-Maedi Visna, e uma soroprevalência alta e generalizada de B. ovis, Leptospira spp. e T. gondii entre animais e rebanhos.

Palavras-chave: Brucelose. C. pseudotuberculosis. Leptospira spp. Maedi-Visna. T. gondii. Ovinos. Sorodiagnóstico.

\section{Correspondence to:}

Marcos Bryan Heinemann

Universidade de São Paulo, Faculdade de Medicina Veterinária

e Zootecnia, Departamento de Medicina Veterinária

Preventiva e Saúde Animal

Av. Prof. Dr. Orlando Marques Paiva, 87

CEP: 05508-270, São Paulo - SP, Brazil

e-mail: marcosbryan@usp.br

Received: November 20, 2019

Approved: February 26, 2020
How to cite: Dorneles EMS, Guimarães AS, Gouveia AMG, Coura FM, Carmo FB, Pauletti RB, Azevedo V, Lilenbaum W, Vitor RWA, Pinheiro RR, Ferreira ACR, Dasso MG, Lage AP, Heinemann MB. Seroprevalence of Brucella ovis-epididymitis, smooth-Brucella, leptospirosis, toxoplasmosis, and Maedi-Visna in sheep slaughtered in Minas Gerais State, Brazil. Braz J Vet Res Anim Sci. 2020;57(2):e164278. https://doi.org/10.11606/issn.16784456.bjvras.2020.164278

\section{Introduction}

In Minas Gerais State, Brazil, the number of sheep has increased $93.11 \%$ in recent years; from 116,796 in 2000 to 225,549 in 2008 (Instituto Brasileiro de Geografia e Estatística, 2008). This is much greater than the overall Brazilian growth, which recorded a $12.5 \%$ increase in sheep herds during the same period (Instituto Brasileiro de Geografia e Estatística, 2008). The rapid growth of commercial sheep herds is due to an expansion of sheep meat markets in all regions of the country. Despite the significant raise in Brazilian production of lamb, this is still insufficient to supply consumer's demands. Consequently, many breeders of beef cattle are now investing in sheep husbandry, with the acquisition of animals from other Brazilian regions. This increase in sheep production has resulted in considerable transit of animals into Minas Gerais State, with acquisition of animals mainly from the Northeast
Region (McManus et al., 2019; Instituto Brasileiro de Geografia e Estatística, 2008).

Information on the sanitary status of sheep slaughtered is a good parameter to evaluate the epidemiological situation of important diseases of economic and public health significance, besides being less expensive than conventional surveys.

Brucellosis is a zoonotic disease caused by Brucella spp. It is widespread, and affects different animal species besides humans (Bovine brucellosis..., 2009). In sheep, it is usually caused by Brucella melitensis, a smooth Brucella species, and the economic importance of ovine brucellosis is based on direct losses and on sanitary barriers to international trade of animals and their products (Corbel et al., 2006). Ovine contagious epididymitis is predominantly associated with Brucella ovis infection, a rough Brucella species (Burgess, 1982). Infection with Brucella abortus, another smooth species, is rare, but both may cause sporadic abortion (Allsup, 1969; Ocholi et al., 2005). In Brazil, serological surveys suggests that $B$. melitensis is exotic in the country (Poester et al., 2002), but infection by B. abortus and B. ovis are present (Azevedo et al., 2004; Carvalho et al., 2010; Clementino et al., 2007; Marques, 2006; Nozaki et al., 2004; Pinheiro et al., 2008, 2009).

The agent of Leptospirosis, Leptospira spp., is worldwide distributed and the seroprevalence in sheep varies according to the region, however serovars Hardjo, Pomona, Grippotyphosa and Bratislava are the most frequently reported in sheep (Faine et al., 2000). In Europe, the disease is prevalent (4.2\% to $49.3 \%$ ), and Pomona and Hardjo are the predominant serovars (Leon-Vizcaino et al., 1987). In a study conducted in New Zealand, 5.7\% of the flocks were seropositive, with predominance of serovars Hardjo and Pomona (Dorjee et al., 2008). In a sheep survey conducted in the State of Rio Grande do Sul, Brazil, the most prevalent (30.7\%) serovar was Hardjo, followed by serovar Sentot (16.8\%) (Herrmann et al., 2004). In Minas Gerais, although leptospirosis was already detected, vaccination against leptospirosis is not frequent among sheep flocks (Guimarães et al., 2009a). 
Ovine toxoplasmosis, caused by Toxoplasma gondii, is responsible for reproductive losses due to abortion and neonatal death. It causes between 1 and $2 \%$ of neonatal losses per year in sheep from United Kingdom (Buxton et al., 2007). The worldwide serum prevalence of ovine toxoplasmosis during 1989-2009 ranged from 3\% in Pakistan to 92\% in Serbia (Dubey, 2009; Kamani et al., 2010; Zedda et al., 2010). In Brazil, serological surveys in small ruminants show infection rates ranging from $30 \%$ to $50 \%$ (Carneiro et al., 2009; Romanelli et al., 2007; Ueno et al., 2009).

Maedi-visna virus (MVV) and Caprine arthritisencephalitis virus (CAEV) initially isolated in sheep and goats, respectively, are retroviruses from the Lentivirus genus assigned to a single group, currently referred to as small ruminant lentiviruses (SRLVs) (Caroline et al., 2010). SRLV s are responsible for significant economic losses, such as decrease in milk production (Smith \& Cutlip, 1988; Snowder et al., 1990), due to mastitis, decrease in weight gain of lambs (Dungu et al., 2000), reduce in animal lifespan and increase in mortality rates (Arsenault et al., 2003; Sigurdsson et al., 1952). In Brazil, MVV seropositive sheep were detected in 1988 in Rio Grande do Sul from imported animals and in herds with a history of importing animals (Dal Pizzol et al., 1989). Thereafter, there were records of the disease in some Brazilian States (Lombardi et al., 2009; Oliveira et al., 2006; Sotomaior \& Milczewski, 1997; Yorinori, 2001; Yorinori et al., 2003).

Corynebacterium pseudotuberculosis is the causative agent for caseous lymphadenitis (CLA) in goats and sheep. CLA is also a very important disease of sheep production worldwide, with prevalence varying from $3.6 \%$ to $100 \%$ of infected animals (Guimarães et al., 2011b). It is distributed in Brazil mainly in the northeast states such as Ceará with 24.6\% herd prevalence, Paraíba with $28.9 \%$, Rio Grande do Norte with 33.2\% and Piauí with 33.7\% (Linfadenite..., 2019). Minas Gerais State its prevalence in sheep was estimated in $70.9 \%$, with $95.9 \%$ of flocks infected (Guimarães et al., 2009b). CLA was found in $43.7 \%$ of slaughtered sheep in Minas Gerais State (Guimarães et al., 2011a). Although the presence of infection by the diseases is by itself a health problem in the flock, very little is known about the simultaneous occurrence of those diseases in sheep or their flocks. Therefore, the aims of the present study were (i) to determine the seroprevalence of brucellosis, B. ovis-epididymitis, leptospirosis, toxoplasmosis and Maedi-visna infection in slaughtered sheep in Minas Gerais State, Brazil and (ii) to study their simultaneous occurrence, including caseous lymphadenitis, at sheep and flock levels.

\section{Material and Methods}

\section{Sampling}

This study was conducted at a sheep slaughterhouse with Federal Inspection Service, localized in the municipality of Patrocínio, Minas Gerais State, Brazil. Visits to the slaughterhouse were made every 30 days, between July and December 2007. Blood samples were collected by jugular vein puncture from animal that were slaughter under humane conditions. Around one animal among each three slaughtered ones was sampled, in order to make possible to inspect the lymph nodes following the slaughter line of the slaughterhouse. Serum was separated by centrifugation and stored at $-20^{\circ} \mathrm{C}$ until tested. Serum samples from 594 animals from 21 flocks were tested.

\section{Serologic assays}

The agar gel immunodiffusion (AGID) employing B. ovis soluble antigen (Instituto de Pesquisas Veterinárias Desidério Finamor [IPVDF], Brazil) was performed as previously described (Souza et al., 2002). The Rose Bengal (RB) test (Tecpar, Brazil) was used as screening test according to Ferreira et al. (2003), and the 2-mercaptoethanol test (2ME) (Tecpar, Brazil) as a confirmatory test for the detection of anti-smooth Brucella (B. abortus and B. melitensis) antibodies (Manual técnico..., 2006).

For the detection of anti-Leptospira antibodies, sera were examined by microscopic agglutination test (MAT), using 24 serovars representing all the described serogroups (Table 1). Sera with titers $\geq 100$ were considered reactive and the antigen that presented the highest titer was considered as the infective serovar (Faine et al., 2000).

Sera were assayed in duplicate by an in-house ELISA for the detection of IgG antibodies to Toxoplasma gondii (Van der Puije et al., 2000) with slight modifications. Briefly, 96-well-plates (Costar, Corning, USA) were coated with $100 \mu \mathrm{L} /$ well $(0.5 \mu \mathrm{g} / 100 \mu \mathrm{L})$ of the soluble tachyzoite antigen (STAg) from T. gondii (RH strain). All the serum

Table 1 - Serovars of Leptospira spp. used in the microscopic agglutination test (MAT) for testing sheep slaughtered in Minas Gerais State, Brazil

\begin{tabular}{lll}
\hline \multicolumn{1}{c}{ Serogroups } & \multicolumn{1}{c}{ Serovar } & \multicolumn{1}{c}{ Strain } \\
\hline Australis & Australis & Ballico \\
& Bratislava & Jez Bratislava \\
Autumnalis & Autumnalis & Akiyamy A \\
Ballum & Castelonis & Castellon 3 \\
Bataviae & Bataviae & Swart \\
Canicola & Canicola & Hond Utrecht IV \\
Grippotyphosa & Grippotyphosa & Moskva V \\
Hebdomadis & Hebdomadis & Hebdomadis \\
Icterohaemorrhagiae & Icterohaemorrhagiae & RGA \\
Mini & Szwajizak & Szwajizak \\
Pomona & Pomona & Pomona \\
Pyrogenes & Pyrogenes & Salinem \\
Sejroe & Hardjo & Hardjoprajitno \\
& Wolffi & 3705 \\
Tarassovi & Tarassovi & Perepelicin \\
\hline
\end{tabular}


samples were tested at a dilution of 1:400. Peroxidase-labelled donkey IgG anti-sheep IgG A-3415 (Sigma-Aldrich, USA) was used as a secondary antibody at a 1:7500 dilution. Six negative sera and two positive sera, previously tested by an indirect fluorescent antibody test (Andrade et al., 2013), were included as control. The cut-off value for each ELISA plate was calculated as the absorbance mean of six serum samples of sheep tested negative for T. gondii, plus three standard deviations tested on each plate.

Antibodies anti-Maedi Visna virus were tested by a commercial AGID kit (Biovetech, Brazil), following manufacturer's instructions.

\section{Data analysis}

Prevalences and confidence intervals were calculated as previously described (Bennett et al., 1991; Noordhuizen et al., 2001) using the packages binGroup (Zhang et al., 2011) and epiR (Stevenson et al., 2012) of Rsoftware version 2.14.1 (R Development Core Team, 2015).

Correspondence analysis (Greenacre \& Blasius, 2006) was used to study the occurrence of the diseases and its relationship with positivity and negativity of sheep and herd size using the InfoStat version 2015 (Di Rienzo et al., 2015). In the correspondence analyzes, the relationship between the categories was represented in a two-dimensional graph. The relatedness between disease diagnostic results and sheep herd size was demonstrated by evaluating which variables were plotted closely together. Data on antibodies anti-C. pseudotuberculosis, previously obtained (Guimarães et al., 2011a), were included in the evaluation of simultaneous infection and in correspondence analysis.

\section{Results}

During the period of the study, 594 serum samples of sheep from 21 flocks were collected at the slaughterhouse. Sampled flocks were located in 16 different municipalities of Minas Gerais State and in two municipalities from nearby states, Vicentinópolis, in the State of Goiás and Ribeirão Preto in the State of São Paulo (Table 2). The mean number of sampled animals per flock was 28.29 (range: 2 to 106).

Seroprevalence of animals and flocks for all investigated diseases are summarized in Table 3. Data of CLA seroprevalence from the same sampling frame previously published (Guimarães et al., 2011a) was included in the analysis of occurrence of simultaneous infection and in correspondence analysis. The distribution of co-infections at animal and flock levels, for all studied diseases, including CLA data (Guimarães et al., 2011a), is shown in Tables 4 and 5, respectively.

Correspondence analysis was performed to evaluate the relationship between the occurrence of the serum antibodies in sheep and the herd size. The representation of the two dimensions and expression of the values of the third dimension are shown in Figure 1. Those three dimensions explains $48.61 \%$ of the total variation, with $16.92 \%$ explained by 1 st dimension, $16.57 \%$ by the 2 st dimension and $15.12 \%$ by the $3^{\text {rd }}$ dimension.

Table 2 - Number of animals sampled by municipality and statel

\begin{tabular}{ccc}
\hline Property Number & City and State & Number of animals \\
\hline 32 & Bonfinópolis-MG & 37 \\
38 & Campina Verde-MG & 2 \\
20 & Frutal-MG & 26 \\
43 & Frutal-MG & 11 \\
58 & Itauna-MG & 3 \\
1 & João Pinheiro-MG & 41 \\
4 & Oliveira-MG & 28 \\
40 & Paraopeba-MG & 9 \\
42 & Patrocinio-MG & 35 \\
21 & Perdizes-MG & 106 \\
46 & Porteirinha-MG & 10 \\
17 & Prata-MG & 16 \\
41 & Ribeirao Preto-SP & 39 \\
45 & Teofilo Otoni-MG & 53 \\
23 & Uberaba-MG & 16 \\
31 & Uberaba-MG & 46 \\
35 & Uberaba-MG & 15 \\
33 & Uberlandia-MG & 17 \\
44 & Unai-MG & 28 \\
13 & Várzea da Palma-MG & 37 \\
34 & Vicentinópolis-GO & 19 \\
Total & & 594 \\
\hline
\end{tabular}

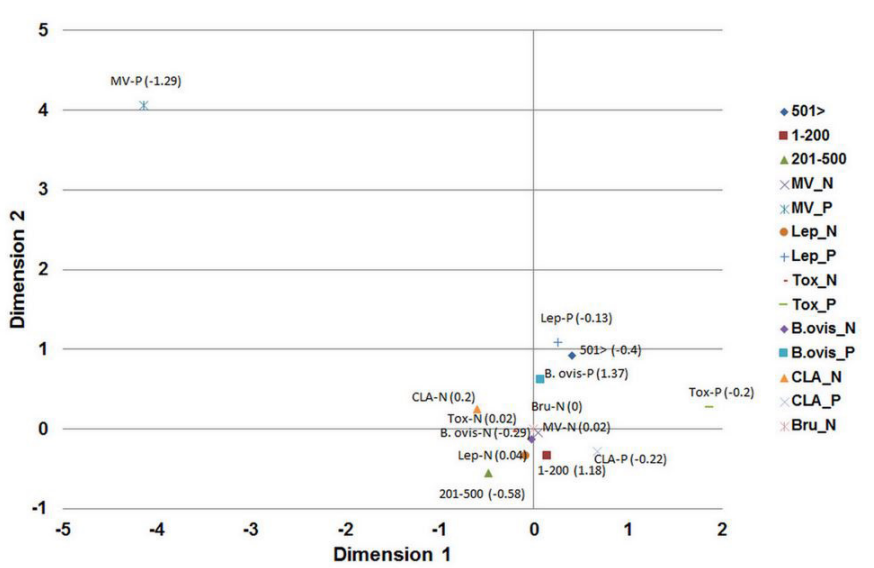

Figure 1. Correspondence analysis of the relationship between the occurrence of seropositivity to brucellosis (Bru_N= seronegatives), B. ovis-epididymitis (B. ovis_ $\mathrm{N}=$ seronegatives; $B$. ovis_ $\mathrm{P}=$ seropositives), leptospirosis (Lep_N $\mathrm{N}=$ seronegatives; Lep_ $\mathrm{P}=$ seropositives), toxoplasmosis (Tox_N= seronegatives; Tox $\mathrm{P}=$ seropositives), Maedi-Visna (MV_N= seronegatives; MV_P = seropositives) and caseous lymphadenitis $\left(\mathrm{CLA}_{-} \mathrm{N}=\right.$ seronegatives; CLA_P $=$ seropositives) in sheep and the herd size $(1-200,201-500$ and $>501)$. This three dimensional representation explains $48.61 \%$ of the total variation, with $16.92 \%$ explained by 1 st dimension, $16.57 \%$ by the 2 st dimension and $12 \%$ by the 3 rd dimenson. The correspondence analysis dimensional representation is interpreted by considering which categories are plotted closely together. 
Table 3 - Sheep and flock seroprevalence of brucellosis, B. ovis-epididimitis, leptospirosis, toxoplasmosis and Maedi-Visna in sheep slaughtered in Minas Gerais State, Brazil, 2007

\begin{tabular}{|c|c|c|c|c|c|c|c|c|c|c|c|c|}
\hline \multirow{4}{*}{ Disease } & \multicolumn{6}{|c|}{ Animal Prevalence } & \multirow{2}{*}{\multicolumn{3}{|c|}{$\begin{array}{r}\text { Flock Prevalence } \\
95 \% \mathrm{Cl}(\%)\end{array}$}} & \multicolumn{3}{|c|}{ Parameters of the tests } \\
\hline & \multicolumn{3}{|c|}{ Apparent Prevalence } & \multicolumn{3}{|c|}{ True Prevalence } & & & & \multicolumn{2}{|c|}{$\%$} & \multirow{3}{*}{ Ref. } \\
\hline & \multirow{2}{*}{$\%$} & \multicolumn{2}{|c|}{$95 \% \mathrm{Cl}(\%)^{*}$} & \multirow{2}{*}{$\%$} & \multicolumn{2}{|c|}{$95 \% \mathrm{Cl}(\%)$} & \multirow{2}{*}{$\%$} & \multirow{2}{*}{ Min. } & \multirow{2}{*}{ Max. } & \multirow{2}{*}{ Sen } & \multirow{2}{*}{ Spe } & \\
\hline & & Min. & Max. & & Min. & Max. & & & & & & \\
\hline Brucellosis & 0.00 & 0.00 & 0.001 & 0.00 & 0.00 & 0.06 & 0.00 & 0.00 & 16.11 & 98.60 & 100.00 & $\begin{array}{c}\text { Ferreira et al. (2003), } \\
\text { Nielsen (2002) }\end{array}$ \\
\hline B. ovis infection & 16.64 & 15.17 & 18.10 & 24.04 & 22.67 & 25.46 & 80.95 & 58.09 & 94.55 & 69.20 & 100.00 & Xavier et al. (2011) \\
\hline Leptospira spp. & 28.15 & 22.49 & 33.82 & 25.96 & 24.74 & 27.20 & 90.48 & 69.62 & 98.83 & 98.20 & 96.40 & Bajani et al. (2003) \\
\hline Hardjo & 17.57 & 14.69 & 20.44 & 14.76 & 13.74 & 15.82 & 90.48 & 69.62 & 98.83 & & & \\
\hline Icterohaemorrhagiae & 8.22 & 4.43 & 12.00 & 4.88 & 4.15 & 5.66 & 52.38 & 29.78 & 74.29 & & & \\
\hline Hebdomadis & 0.00 & 0.00 & 0.001 & 0.00 & 0.00 & 0.00 & 0.00 & 0.00 & 16.11 & & & \\
\hline Bratislava & 2.22 & 0.98 & 3.45 & 0.00 & 0.00 & 0.00 & 47.62 & 25.71 & 70.22 & & & \\
\hline Pomona & 0.00 & 0.00 & 0.001 & 0.00 & 0.00 & 0.00 & 0.00 & 0.00 & 16.11 & & & \\
\hline Grippotyphosa & 2.30 & 1.59 & 3.01 & 0.00 & 0.00 & 0.00 & 47.62 & 25.71 & 70.22 & & & \\
\hline Toxoplasmosis & 9.57 & 5.77 & 13.38 & 10.46 & 9.33 & 11.66 & 71.43 & 47.82 & 88.72 & 68.40 & 97.30 & $\begin{array}{l}\text { Van der Puije et al. } \\
\qquad(2000)\end{array}$ \\
\hline $\begin{array}{l}\text { Maedi-Visna } \\
\text { infection }\end{array}$ & 2.46 & 1.01 & 3.91 & 3.08 & 2.60 & 3.63 & 23.81 & 8.22 & 47.17 & 79.70 & 100.00 & Pinheiro (2001) \\
\hline
\end{tabular}

$* \mathrm{CI}=$ confidence interval.

Table 4 - Distribution of co-infections in sheep slaughtered in Minas Gerais State, Brazil, 2007

\begin{tabular}{|c|c|c|c|c|c|c|}
\hline $\mathrm{CLA}^{1}$ & Leptospirosis & B. ovis & Toxoplasmosis & Maedi-Visna & Sheep & $\%$ \\
\hline $\mathrm{Neg}^{2}$ & $\mathrm{Neg}$ & $\mathrm{Neg}$ & $\mathrm{Neg}$ & $\mathrm{Neg}$ & 177 & 30.05 \\
\hline $\mathrm{POS}^{3}$ & Neg & $\mathrm{Neg}$ & $\mathrm{Neg}$ & $\mathrm{Neg}$ & 156 & 26.49 \\
\hline Neg & POS & Neg & Neg & Neg & 58 & 9.85 \\
\hline POS & POS & $\mathrm{Neg}$ & $\mathrm{Neg}$ & Neg & 43 & 7.30 \\
\hline Neg & Neg & POS & $\mathrm{Neg}$ & Neg & 35 & 5.94 \\
\hline POS & Neg & POS & $\mathrm{Neg}$ & Neg & 30 & 5.09 \\
\hline POS & Neg & Neg & POS & Neg & 24 & 4.07 \\
\hline Neg & POS & POS & $\mathrm{Neg}$ & Neg & 13 & 2.21 \\
\hline POS & POS & POS & $\mathrm{Neg}$ & Neg & 11 & 1.87 \\
\hline Neg & Neg & Neg & POS & Neg & 10 & 1.70 \\
\hline POS & POS & Neg & POS & Neg & 9 & 1.53 \\
\hline Neg & Neg & POS & POS & Neg & 7 & 1.19 \\
\hline Neg & POS & Neg & POS & Neg & 5 & 0.85 \\
\hline Neg & Neg & Neg & $\mathrm{Neg}$ & POS & 4 & 0.68 \\
\hline POS & Neg & POS & POS & Neg & 4 & 0.68 \\
\hline Neg & Neg & POS & Neg & POS & 1 & 0.17 \\
\hline $\mathrm{Neg}$ & POS & Neg & $\mathrm{Neg}$ & POS & 1 & 0.17 \\
\hline $\mathrm{Neg}$ & POS & POS & Neg & POS & 1 & 0.17 \\
\hline POS & POS & POS & POS & $\mathrm{Neg}$ & 1 & 017 \\
\hline
\end{tabular}

${ }^{1}$ CLA: Caseous lymphadenitis; ${ }^{2}$ Neg: negative; ${ }^{3}$ POS: positive.

Table 5 - Distribution of co-infections among the 21 flocks supplying sheep to a slaughterhouse in the State of Minas Gerais, Brazil, 2007

\begin{tabular}{|c|c|c|c|c|c|c|}
\hline CLA $^{1}$ & Leptospirosis & B. ovis & Toxoplasmosis & Maedi-Visna & Flocks & $\%$ \\
\hline $\mathrm{POS}^{3}$ & POS & POS & POS & POS & 4 & 19.05 \\
\hline POS & POS & POS & POS & Neg & 8 & 38.10 \\
\hline POS & POS & POS & Neg & Neg & 4 & 19.05 \\
\hline POS & POS & Neg & POS & POS & 1 & 4.76 \\
\hline POS & POS & Neg & POS & Neg & 1 & 4.76 \\
\hline POS & POS & Neg & Neg & Neg & 1 & 4.76 \\
\hline POS & $\mathrm{Neg}^{2}$ & POS & POS & $\mathrm{Neg}$ & 1 & 4.76 \\
\hline POS & Neg & $\mathrm{Neg}$ & Neg & Neg & 1 & 4.76 \\
\hline
\end{tabular}

${ }^{1} \mathrm{CLA}$ : Caseous lymphadenitis; ${ }^{2} \mathrm{Neg}$ : negative; ${ }^{3} \mathrm{POS}$ : positive. 


\section{Discussion}

Results from the present study showed that a large proportion of sheep slaughtered in Minas Gerais State exhibited antibodies against Leptospira spp., B. ovis or T. gondii and that those antibodies were also highly prevalent at flock level. Moreover, evidence of infection or exposure to more than one of the studied agents was very frequent, about $60 \%$ of the flocks showed antibodies against four or more of them (Table 5). However, serum antibodies against more than one of the studied pathogens (Table 4) were simultaneously observed only $25.47 \%$ of the sheep.

Data from the state agency for animal health (Instituto Mineiro de Agropecuária - IMA) show that, in the last years, there was a large influx of animals from different states of the country (Bahia, Distrito Federal, Espírito Santo, Goiás, Rio de Janeiro, Sergipe, and São Paulo) to Minas Gerais State, mainly for reproduction. This large transit of animals towards Minas Gerais, associated with the absence of specific national health legislation for sheep, could have favored the introduction of and can explain the widespread distribution of the studied diseases into sheep slaughtered in the State (Guimarães et al., 2009b). The observation that only about $30 \%$ of the sampled population (Table 3 ) was free from infection of the infectious agents studied or C. pseudotuberculosis (Guimarães et al., 2011a) is of great concern. The diseases evaluated in the present study and CLA, previously studied in the same population (Guimarães et al., 2011a), are associated with major economic losses to sheep production worldwide (Guimarães et al., 2011b) and some of them are also related to important public health issues. Our results indicate an urgent need for implementation of sheep health programs to control those major diseases in Minas Gerais by flock owners and state animal health agents in order to improve the sanity and productivity of sheep in the State.

The high rate of antibodies against Leptospira spp., B. ovis and T. gondii observed in the present study suggests that infection by these microorganisms may play an important role in the etiology of reproductive problems in sheep in the region, since leptospirosis, B. ovis-epididymitis and toxoplasmosis are major causes of abortion and reproductive failure in sheep (Burgess, 1982; Carvalho et al.; 2010; Innes et al., 2009; Lilenbaum et al., 2009). Corroborating this hypothesis, it is important to take into account that our finding showed that $8.5 \%$ of the slaughtered animals showed antibodies against to two or more of those three agents of reproductive diseases (Table 4) and that abortion is frequently reported in sheep flocks from Minas Gerais (23.9\%, 51/213) (Guimarães et al., 2009a).
Anti-Leptospira antibodies were the most prevalent and widely distributed at both levels, sheep and flock. It was only surpassed by CLA, which was previously shown to have a higher seroprevalence using the same sampling frame (Guimarães et al., 2011a). These high rates of serologic evidence of infection by Leptospira spp. in sheep were expected, since previous studies reported similar rates in other countries or in other Brazilian States (Dorjee et al., 2008; Herrmann et al., 2004; Martins et al., 2012). Moreover, in the survey performed by Guimarães et al. (2009b) using 213 sheep flocks in Minas Gerais State, only 2 (1.0\%) reported the use of vaccination against leptospirosis, which supports our findings. The most common reactions were directed towards serovar Hardjo, as previously reported in sheep and goat flocks from Brazil (Herrmann et al., 2004; Martins et al., 2012), which could probably be due to close contact between sheep and cattle. The serovar Icterohaemorrhagiae, the second most prevalent in animal and flocks, was also among the most frequently related to infection in Brazilian sheep (Martins et al., 2012; Melo et al., 2010). Analysis of the Table 3 suggests that only infection by serovars Harjo and Icterohaemorrhagiae are epidemiologically significant, as the true prevalence and its confidence interval for infection by the other tested serovars showed null results. Another important aspect associated to the high seroprevalence of leptospirosis is its impact in public health since sheep are carriers of bacteria in kidneys over a long period (Dorjee et al., 2008). This prolonged elimination could constitute a zoonotic risk for people in contact with the sheep, as handlers, farmers and workers in slaughterhouses. The management of reproductive animals or the lack of vaccination, which are more difficult in larger herds, can also contribute to the spread of the disease.

Serological surveys in other States have shown the presence of the B. ovis in sheep in different regions of the country with large differences in the frequencies of positive animals. Studies carried out in the state of Paraíba and Bahia showed $8.59 \%$ of seropositive herds and $3.27 \%$ seropositive animals among 183 sera tested, respectively (Clementino et al., 2007; Silva et al. 2009). Moreover, in 2013, a study carried out by Araújo et al. (2013) also in Bahia, observed 6.94\% positive animals among 793 sampled, whereas in Rio Grande do Sul in 2015, 2.89\% of 1800 animals analyzed were seropositive (Machado et al., 2015).

Our findings for B. ovis-epididymitis suggest that the infection is highly spread among herds and animals slaughtered in Minas Gerais State. Despite comparisons among the present results and others are difficult due differences in experimental designs, ours results suggest a great increase 
in seroprevalence of $B$. ovis in sheep population in Minas Gerais, as a 2002 study estimated a seroprevalence of 5.3\% for animals and of $29.4 \%$ for herds in the State (Marques, 2006). This increase in seroprevalence could be explained by the high influx of sheep into flocks of Minas Gerais State, which is associated to its recent establishment and to the introduction of animals from different regions of country, which effectively contributes to the spread of infectious diseases. Furthermore, just a small fraction of animals that move from flock to flock are usually tested for B. ovis infection (Marques, $2006)$ and only a few sheep flock owners (14/213, 11.7\%) requires any animal health statement for the introduction of sheep into their flocks (Guimarães et al., 2009a). Those findings indicate that the polices of the Programa Nacional de Sanidade de Caprinos e Ovinos (National Caprine and Ovine Health Program) should be quickly implemented in order to reduce the prevalence and incidence of infection by B. ovis among sheep in Minas Gerais State (Ministério da Agricultura, Pecuária e Abastecimento, 2005).

Our findings concerning brucellosis confirm previously unpublished data from our group on Minas Gerais State and also studies in other Brazilian States (Poester et al., 2002), which point toward that Brazil is free from B. melitensis infection. The other possibly source of smooth Brucella spp. infection to sheep, in the absence of $B$. melitensis infection, is the close contact with cattle, which is the natural hosts of B. abortus. The establishment of a compulsory vaccination program in the early 1990's markedly reduced the seroprevalence of bovine brucellosis in Minas Gerais State to levels lower than $1.0 \%$ of infected animals reported in 2002 (Gonçalves et al., 2009). The absence of any brucellosis seropositive sheep from our sampling seems to be also influenced by this low rate of B. abortus infected cattle in the State.

For T. gondii, the data showed high flock seroprevalence (71.43\%), although a low proportion of animals (9.57\%) present serological evidence of the infection. High sheep flock seroprevalence (66.7\%) was also found in a study in Central Ethiopia (Gebremedhin et al., 2013). Similar results for sheep prevalence $(7.7 \%, 7.0 \%, 11 \%)$ were found by others (Moura et al., 2007; Silva \& Langoni, 2001) in Rio Grande do Sul, Paraná and São Paulo States. However, higher seroprevalences (38.22\% and $43.2 \%$ for animals, respectively, and $100 \%$ for herds) were observed in Federal District, central region of Brazil (Ueno et al., 2009) and Minas Gerais State (Carneiro et al., 2009), the second largest sheep population in the southern region of Brazil (Instituto Brasileiro de Geografia e Estatística, 2008). The use of different serological tests and cut-off values may have accounted for the difference in these serological studies (Dubey, 2009). The observed high frequency of positive herds can also be associated to the intense traffic of animals into the State as stated before. Furthermore, the low prevalence of antibodies in studied sheep may be related to the use of appropriate management techniques that could have prevented the contamination of the environment by oocysts of $T$. gondii excreted in cat feces. Nevertheless, this low animal prevalence is still of concern because undercooked meat from infected animals is one of the major sources of human infection by T. gondii. Indeed, children under 18 are 2.4 times more likely to become seropositive when there is the consumption of rare meat (Schlundt et al., 2004). Furthermore, toxoplasmosis is of great public health concern in Brazil because there is a higher risk of Brazilian children developing severe toxoplasmosis than children in Europe (Jones \& Dubey, 2012).

Antibodies against Maedi-visna virus were the lowest prevalent of all studied diseases at both levels, animal and flock. Similar results were also observed in the State of São Paulo (Lombardi et al., 2009), where the production system resembled that of Minas Gerais. Worldwide, lentivirus infection is associated to intensive production system and to the international movement of European breeds (Manual of diagnostic..., 2008). Similarly to our findings, a previous study in Minas Gerais State (Marques, 2006) also observed a low seroprevalence of Maedi-visna virus, besides an association of the infection with purchase of breeding animals and intensive production. Therefore, the low frequency of antibodies anti- Maedi-visna depicted in the present study is probably associated to the extensive rearing system, common to meat-producing sheep flocks, and used by all sheep owners interviewed (Guimarães et al., 2011a).

In the correspondence analysis, the negativity of sheep for all the studied diseases was plotted close together, suggesting that some herd biosecurity measures to control disease spread may be used in the negative flocks. Considering that the seropositivity for Maedi-Visna and toxoplasmosis were plotted further apart from other variables, it is tempting to speculate that these results may be due to the main form of transmission of these diseases, contaminated milk and colostrum for Maedi-Visna and presence of cats in feeds and barns facilities for T. gondii, are not related to the other studied pathogens. This observation is also possible for CLA, B. ovis and leptospirosis, since seropositivity for these diseases were associated at some level (Figure 1), which may have occurred because of the proximity of animals and environment contamination that augments the exposure to the infectious agents. Also, the correspondence analysis indicated that the occurrence of leptospirosis was higher in larger flocks (more than 501 animals), while smaller flocks (1-200 and 201-500) tended to be negative for the disease. 


\section{Conclusions}

In summary, data from the present study on sheep slaughtered in Minas Gerais, Brazil, showed no antibodies against smooth-Brucella and a low frequency of antibodies anti-Maedi Visna, but that seroprevalence of B. ovis, Leptospira spp., and T. gondii are high and widespread among animals and flocks. Moreover, simultaneous occurrence of antibodies of those agents and C. pseudotuberculosis were present in the majority of herds, while only a few animals showed seropositivity for more than one agent.

\section{Conflict of Interest}

The authors declare that they do not have any conflict of interest.

\section{References}

Allsup TN. Abortion in sheep associated with Brucella abortus infection. Vet Rec. 1969;84(5):104-8. http://dx.doi. org/10.1136/vr.84.5.104. PMid:4978562.

Andrade MM, Carneiro M, Medeiros AD, Andrade V No, Vitor RW. Seroprevalence and risk factors associated with ovine toxoplasmosis in Northeast Brazil. Parasite. 2013;20:20. http://dx.doi.org/10.1051/parasite/2013019. PMid:23707895.

Araújo B, Costa J, Souza T, Lima CC, Leite MD, Costa A No, Anunciação AV, Almeida MG, Lima E. Seroepidemiology of sheep brucellosis in the microregion of Feira de Santana, BA, Brazil. Braz J Vet Res Anim Sci. 2013;50(2):129-35. http://dx.doi.org/10.11606/issn.2318-3659.v50i2p129-135.

Arsenault J, Dubreuil P, Girard C, Simard C, Belanger D. Maedi-visna impact on productivity in Quebec sheep flocks (Canada). Prev Vet Med. 2003;59(3):125-37. http://dx.doi. org/10.1016/S0167-5877(03)00086-2. PMid:12809758.

Azevedo SS, Alves CJ, Alves FAL, Inácio JC, Batista CSA, Azevedo AS. Ocorrência de anticorpos anti-Brucella ovis em ovinos procedentes de quatro municípios do Estado do Rio Grande do Norte. Agrop Tec. 2004;25:45-50.

Bajani MD, Ashford DA, Bragg SL, Woods CW, Aye T, Spiegel RA, Plikaytis BD, Perkins BA, Phelan M, Levett PN, Weyant RS. Evaluation of four commercially available rapid serologic tests for diagnosis of leptospirosis. J Clin

\section{Ethics Statement}

The procedures involving animals were approved by the Ethics committee on the use of animals at the Federal University of Minas Gerais.

\section{Acknowledgements}

This study was supported by the Conselho Nacional de Desenvolvimento Científico e Tecnológico - CNPq, Fundação de Amparo à Pesquisa do Estado de Minas Gerais - Fapemig and FEPMVZ Coordenação Preventiva. EMSD, RBP, VA, WL, RWAV, APL and MBH thank CNPq for the fellowships. Rio Branco Alimentos is also acknowledged for its help in sampling and herd data acquisition.

Microbiol. 2003;41(2):803-9. http://dx.doi.org/10.1128/ JCM.41.2.803-809.2003. PMid:12574287.

Bennett S, Woods T, Liyanage WM, Smith DL. A simplified general method for cluster sample-surveys of health in developing countries. World Health Stat. 1991;44(3):98106. PMid:1949887.

Ministério da Agricultura, Pecuária e Abastecimento (Brasil). Instrução normativa ${ }^{\circ} 20$, de 15 de agosto de 2005. Aprova os procedimentos para operacionalização do cadastro sanitário de estabelecimentos de criação de caprinos e ovinos. Diário Oficial da União; 2005 Sept 12.

Manual técnico do Programa Nacional de Controle e Erradicação da Brucelose e Tuberculose - PNCEBT. Brasília: Ministerio da Agricultura Pecuária e Abastecimento; 2006.

Burgess GW. Ovine contagious epididymitis: a review. Vet Microbiol. 1982;7(6):551-75. http://dx.doi.org/10.1016/03781135(82)90049-9. PMid:6762755.

Buxton D, Maley SW, Wright SE, Rodger S, Bartley P, Innes EA. Toxoplasma gondii and ovine toxoplasmosis: new aspects of an old story. Vet Parasitol. 2007;149(1-2):25-8. http:// dx.doi.org/10.1016/j.vetpar.2007.07.003. PMid:17686585.

Carneiro AC, Carneiro M, Gouveia AM, Guimarães AS, Marques AP, Vilas-Boas LS, Vitor RW. Seroprevalence and risk factors of sheep toxoplasmosis in Minas Gerais, 
Brazil. Vet Parasitol. 2009;160(3-4):225-9. http://dx.doi. org/10.1016/j.vetpar.2008.10.092. PMid:19091475.

Caroline L, Minardi CJ, Jean-Francois M. SRLVs: a genetic continuum of lentiviral species in sheep and goats with cumulative evidence of cross species transmission. Curr HIV Res. 2010;8(1):94-100. http://dx.doi. org/10.2174/157016210790416415. PMid:20210785.

Carvalho CA Jr, Xavier MN, Costa LF, Silveira SS, Sant'Anna FM, Borges AM, Gouveia AMG, Santos RL. Agentes infecciosos que podem promover infertilidade em machos da espécie ovina. Rev Bras Reprod Anim. 2010;34:160-7.

Clementino IJ, Alves CJ, Azevedo SS, Paulin LM, Medeiros KA. Inquérito soro-epidemiológico e fatores de risco associados à infecção por Brucella ovis em carneiros deslanados do semi-árido da Paraíba. Pesq Vet Bras. 2007;27(4):137-43. http://dx.doi.org/10.1590/S0100-736X2007000400002.

Corbel MJ, Elberg SS, Cosivi O. Brucellosis in humans and animals. Geneva: World Health Organization; 2006. 189 p.

Dal Pizzol M, Ravazzolo AP, Gonçalves IPD, Hötzel I, Fernandes JCT, Moojen V. Maedi-Visna: evidência de ovinos infectados no Rio Grande do Sul, Brasil, 1987-1989. Acta Sci Vet. 1989;17:65-76.

Di Rienzo JA, Casanoves F, Balzarini MG, Gonzalez L, Tablada M, Robledo CW. InfoStat versión 2015. Argentina: Grupo InfoStat, FCA, Universidad Nacional de Córdoba; 2015.

Dorjee S, Heuer C, Jackson R, West DM, Collins-Emerson JM, Midwinter AC, Ridler AL. Prevalence of pathogenic Leptospira spp. in sheep in a sheep-only abattoir in New Zealand. N Z Vet J. 2008;56(4):164-70. http://dx.doi.org/ 10.1080/00480169.2008.36829. PMid:18690252.

Dubey JP. Toxoplasmosis in sheep: the last 20 years. Vet Parasitol. 2009;163(1-2):1-14. http://dx.doi.org/10.1016/j. vetpar.2009.02.026. PMid:19395175.

Dungu B, Vorster J, Bath GF, Verwoerd DW. The effect of a natural maedi-visna virus infection on the productivity of South African sheep. Onderstepoort J Vet Res. 2000;67(2):8796. PMid:11028744.

Faine S, Adler B, Bolin C, Perolat P. Leptospira and leptospirosis. Meibourne: Australia MedSci; 2000.

Ferreira AC, Cardoso R, Dias IT, Mariano I, Belo A, Preto IR, Manteigas A, Fonseca AP. Evaluation of a modified Rose
Bengal test and an indirect enzyme-linked immunosorbent assay for the diagnosis of Brucella melitensis infection in sheep. Vet Res. 2003;34(3):297-305. http://dx.doi.org/10.1051/ vetres:2003005. PMid:12791239.

Gebremedhin EZ, Agonafir A, Tessema TS, Tilahun G, Medhin G, Vitale M, Di Marco V. Some risk factors for reproductive failures and contribution of Toxoplasma gondii infection in sheep and goats of Central Ethiopia: a cross-sectional study. Res Vet Sci. 2013;95(3):894-900. http://dx.doi.org/10.1016/j.rvsc.2013.08.007

Gonçalves VSP, Delphino MKVC, Dias RA, Ferreira F, Amaku M, Ferreira JS No, Porto TB, Alves CM, Figueiredo VCF, Lôbo JR. Situação epidemiológica da brucelose bovina no Estado de Minas Gerais. Arq Bras Med Vet Zootec. 2009;61(Suppl. 1):35-45. http://dx.doi.org/10.1590/S010209352009000700006.

Greenacre M, Blasius J. Multiple correspondence analysis and related methods. Boca Raton: Chapman \& Hall/CRC; 2006. http://dx.doi.org/10.1201/9781420011319.

Guimarães AS, Carmo FB, Heinemann MB, Portela RW, Meyer R, Lage AP, Seyffert N, Miyoshi A, Azevedo V, Gouveia AM. High sero-prevalence of caseous lymphadenitis identified in slaughterhouse samples as a consequence of deficiencies in sheep farm management in the state of Minas Gerais, Brazil. BMC Vet Res. 2011a;7(1):68. http://dx.doi. org/10.1186/1746-6148-7-68. PMid:22067701.

Guimarães AS, Carmo FB, Pauletti RB, Seyffert N, Ribeiro D, Lage AP, Heinemann MB, Miyoshi A, Azevedo V, Gouveia A, Caseous Lymphadenitis MG. Epidemiology, diagnosis, and control. IIOAB J. 2011b;2:33-43.

Guimarães AS, Gouveia AMG, Abreu AB, Haddad JPA, Leite RC, Carmo FB. Características zoossanitárias da ovinocultura em Minas Gerais. Revista de Veterinária e Zootecnia de Minas. 2009a;102:34-40.

Guimarães AS, Seyffert N, Bastos BL, Portela RWD, Meyer R, Carmo FB, Cruz JCM, McCulloch JA, Lage AP, Heinemann MB, Miyoshi A, Azevedo V, Gouveia AMG. Caseous lymphadenitis in sheep flocks of the state of Minas Gerais, Brazil: prevalence and management surveys. Small Rumin Res. 2009b;87(1-3):86-91. http://dx.doi.org/10.1016/j. smallrumres.2009.09.027.

Herrmann GP; Lage AP, Moreira EC, Haddad JPA, Resende JR, Rodrigues RO, Leite RC. Soroprevalência de aglutininas anti-Leptospira spp. em ovinos nas Mesorregiões Sudeste e Sudoeste do Estado Rio Grande do Sul, Brasil. Cienc 
Rural. 2004;34(2):443-8. http://dx.doi.org/10.1590/S010384782004000200017 .

Innes EA, Bartley PM, Buxton D, Katzer F. Ovine toxoplasmosis. Parasitology. 2009;136(14):1887-94. http:// dx.doi.org/10.1017/S0031182009991636. PMid:19995468.

Instituto Brasileiro de Geografia e Estatística - IBGE. Censo agropecuário 2006 [Internet]. 2008 [cited 2019 Nov 20]. Available from: http://www.sidra.ibge.gov.br

Jones JL, Dubey J. Foodborne toxoplasmosis. Clin Infect Dis. 2012;55(6):845-51. http://dx.doi.org/10.1093/cid/ cis508. PMid:22618566.

Kamani J, Mani AU, Egwu GO. Seroprevalence of Toxoplasma gondii infection in domestic sheep and goats in Borno state, Nigeria. Trop Anim Health Prod. 2010;42(4):793-7. http:// dx.doi.org/10.1007/s11250-009-9488-3. PMid:19882227.

Leon-Vizcaino L, Hermoso de Mendoza M, Garrido F. Incidence of abortions caused by leptospirosis in sheep and goats in Spain. Comp Immunol Microbiol Infect Dis. 1987;10(2):149-53. http://dx.doi.org/10.1016/01479571(87)90009-9. PMid:3304822.

Lilenbaum W, Varges R, Ristow P, Cortez A, Souza SO, Richtzenhain LJ, Vasconcellos SA. Identification of Leptospira spp. carriers among seroreactive goats and sheep by polymerase chain reaction. Res Vet Sci. 2009;87(1):16-9. http://dx.doi.org/10.1016/j.rvsc.2008.12.014. PMid:19232418.

Linfadenite Caseosa (LC) [Internet]. Brasília: Empresa Brasileira de Pesquisa Agropecuária; 2020. [cited 2019 Nov 20]. Available from: https://www.embrapa.br/cim-inteligenciae-mercado-de-caprinos-e-ovinos/zoossanitario-linfadenite

Lombardi AL, Nogueira AHC, Feres FC, Paulo HP, Castro RS, Feitosa FLF, Cadioli FA, Peiró JR, Perri SHV, Lima VFM, Mendes LCN. Soroprevalência de Maedi-Visna em ovinos na região de Araçatuba, SP. Arq Bras Med Vet Zootec. 2009;61(6):1434-7. http://dx.doi.org/10.1590/ S0102-09352009000600025.

Machado G, Santos DV, Kohek I, Stein MC, Hein HE, Poeta AS, Vidor AC, Corbellini LG. Seroprevalence of Brucella ovis in rams and associated flock level risk factors in the state of Rio Grande do Sul, Brazil. Prev Vet Med. 2015;121(12):183-7. http://dx.doi.org/10.1016/j.prevetmed.2015.05.009. PMid:26092724.
Manual of diagnostic tests and vaccines for terrestrial animals. Geneva: World Organisation for Animal Health; 2008 [cited 2019 Nov 20]. Caprine arthritis/encephalitis and Maedi-visna. Available from: http://www.oie.int/ international-standard-setting/terrestrial-manual/accessonline

Marques APR. Caracterização soroepidemiológica da infecção por vírus Maedi-Visna e Brucella ovis em ovinos no estado de Minas Gerais [thesis]. Belo Horizonte: Universidade Federal de Minas Gerais; 2006. 79 s.

Martins G, Penna B, Hamond C, Leite RC, Silva A, Ferreira A, Brandão F, Oliveira F, Lilenbaum W. Leptospirosis as the most frequent infectious disease impairing productivity in small ruminants in Rio de Janeiro, Brazil. Trop Anim Health Prod. 2012;44(4):773-7.http://dx.doi.org/10.1007/ s11250-011-9964-4. PMid:21898182.

McManus C, Hermuche P, Paiva SR, Paula e Silva FC, Moraes JCF, Melo CB, Mendes C. Distribuição geográfica de raças de ovinos no Brasil e sua relação com fatores ambientais e climáticos, como a classificação de risco para a conservação. [cited 2019 Nov 20]. In: ARCO: Assistência aos Rebanho de Criadores de Ovinos [Internet]. Bagé (RS): ARCO, 2019. Available from: http://www.arcoovinos.com.br/images/ artigosTecnicos/Distribuicao\%20Geografica\%20de\%20 racas\%20de\%20Ovinos\%20no\%20Brasil.pdf

Melo LSS, Castro MB, Leite RC, Moreira ÉC, Melo CB. Castro MBd, Leite RC, Moreira ÉC, Melo CBd. Principais aspectos da infecção por Leptospira sp em ovinos. Cienc Rural. 2010;40(5):1235-41. http://dx.doi.org/10.1590/ S0103-84782010005000072.

Moura AB, Osaki SC, Zulpo DL, Marana ERM. Ocorrência de anticorpos contra Toxoplasma gondii em suínos e ovinos abatidos no município de Guarapuava, PR, Brasil. Rev Bras Parasitol Vet. 2007;16(1):54-6. PMid:17588324.

Nielsen K. Diagnosis of brucellosis by serology. Vet Microbiol. 2002;90(1-4):447-59. http://dx.doi.org/10.1016/ S0378-1135(02)00229-8. PMid:12414164.

Noordhuizen JPTM, Frankena K, Thrusfield MV, Graaf EAM. Application of quantitative methods in veterinary epidemiology. Wageningen: Wageningen Pers; 2001. http:// dx.doi.org/10.3920/978-90-74134-89-7.

Nozaki CN, Megid J, Lima KC, Silva FF Jr, Veloso CS. Comparação das técnicas em gel de ágar e ELISA no diagnóstico de Brucelose ovina em Cabanhas da região 
Centro-oeste do estado de São Paulo. Arq Inst Biol. 2004;71(1):1-5.

Ocholi RA, Kwaga JK, Ajogi I, Bale JO. Abortion due to Brucella abortus in sheep in Nigeria. Rev Sci Tech. 2005;24(3):973-9. http://dx.doi.org/10.20506/rst.24.3.1627. PMid:16642768.

Oliveira MMM, Castro RS, Carneiro KL, Nascimento SA, Callado AKC, Alencar CSA, Costa LSP. Anticorpos contra lentivírus de pequenos ruminantes em caprinos e ovinos em abatedouros do estado de Pernambuco. Arq Bras Med Vet Zootec. 2006;58(5):947-9. http://dx.doi.org/10.1590/ S0102-09352006000500035.

Pinheiro JW Jr, Oliveira AAF, Mota RA, Agottani JV, Jesus EM, Assis ST, Oliveira CZ. Ocorrência de ovinos sororeatores para Brucella ovis no estado da Paraíba, Brasil. Revista Veterinaria e Zootecnia. 2009;16:500-8.

Pinheiro JW Jr, Souza MMA, Guerra NR, Santana VLA, Mota RA. Freqüência de aglutininas anti-Brucella abortus em caprinos e ovinos do sertão do estado de Pernambuco, Brasil. Cienc Anim Bras. 2008;9:1096-101.

Pinheiro RR. Vírus da artrite encefalite caprina: desenvolvimento e padronização de ensaios imunoenzimáticos (ELISA e Dot-Blot) e estudo epidemiológico no Estado do Ceará, 2001 [thesis]. Belo Horizonte: Universidade Federal de Minas Gerais; 2001.

Poester FP, Goncalves VS, Lage AP. Brucellosis in Brazil. Vet Microbiol. 2002;90(1-4):55-62. http://dx.doi.org/10.1016/ S0378-1135(02)00245-6. PMid:12414134.

R Development Core Team. A language and environment for statistical computing. Vienna: R Foundation for Statistical Computing; 2015.

Romanelli PR, Freire RL, Vidotto O, Marana ER, Ogawa L, De Paula VS, Garcia JL, Navarro IT. Prevalence of Neospora caninum and Toxoplasma gondii in sheep and dogs from Guarapuava farms, Parana State, Brazil. Res Vet Sci. 2007;82(2):202-7. http://dx.doi.org/10.1016/j. rvsc.2006.04.001. PMid:17266999.

Schlundt J, Toyofuku H, Jansen J, Herbst SA. Emerging food-borne zoonoses. Rev Sci Tech. 2004;23(2):513-33. http://dx.doi.org/10.20506/rst.23.2.1506. PMid:15702717.

Sigurdsson B, Grimsson H, Palsson PA. Maedi, a chronic, progressive infection of sheep's lungs. J Infect Dis.
1952;90(3):233-41. http://dx.doi.org/10.1093/infdis/90.3.233. PMid:14938612.

Silva AV, Langoni $\mathrm{H}$. The detection of Toxoplasma gondii by comparing cytology, histopathology, bioassay in mice, and the polymerase chain reaction (PCR). Vet Parasitol. 2001;97(3):191-8. http://dx.doi.org/10.1016/S03044017(01)00404-6. PMid:11390071.

Silva NS, Barros IN, Dasso MG, Almeida MGAR, Laborda SS, Anunciação AVM, Moreira ELT, Lima AES, Oliveira EMD. Detecção de anticorpos anti- "Brucella ovis" em ovinos do Estado da Bahia. Rev Bras Saúde Prod Anim. 2009;10(4):8.

Smith MC, Cutlip R. Effects of infection with caprine arthritis-encephalitis virus on milk production in goats. J Am Vet Med Assoc. 1988;193(1):63-7. PMid:2843492.

Snowder GD, Gates NL, Glimp HA, Gorham JR. Prevalence and effect of subclinical ovine progressive pneumonia virus infection on ewe wool and lamb production. J Am Vet Med Assoc. 1990;197(4):475-9. PMid:2170310.

Sotomaior C, Milczewski V. Relato de um rebanho ovino infectado pelo vírus Maedi-Visna no estado do Paraná. In: Anais do $25^{\circ}$ Congresso Brasileiro de Medicina Veterinária; 1997; Gramado. Gramado: Editora da Sociedade Veterinária do Rio Grande do Sul; 1997.

Souza LA, Viana RCA, Michalick MSM, Reis JKP, Lage AP. High sero-prevalence of caseous lymphadenitis identified in slaughterhouse samples as a consequence of deficiencies in sheep farm management in the state of Minas Gerais, Brazil. Rev Bras Med Vet. 2002;24:127-31. http://dx.doi. org/10.1186/1746-6148-7-68.

Stevenson M, Nunes T, Sanchez J, Thornton R, Reiczigel J, Robison-Cox J, Sebastiani P. epiR: an R package for the analysis of epidemiological data. Vienna: R Foundation for Statistical Computing; 2012.

Ueno TE, Goncalves VS, Heinemann MB, Dilli TL, Akimoto BM, de Souza SL, Gennari SM, Soares RM. Prevalence of Toxoplasma gondii and Neospora caninum infections in sheep from Federal District, central region of Brazil. Trop Anim Health Prod. 2009;41(4):547-52. http://dx.doi. org/10.1007/s11250-008-9220-8. PMid:18726165.

Van der Puije WN, Bosompem KM, Canacoo EA, Wastling JM, Akanmori BD. The prevalence of anti-Toxoplasma gondii antibodies in Ghanaian sheep and goats. Acta 
Trop. 2000;76(1):21-6. http://dx.doi.org/10.1016/S0001706X(00)00084-X. PMid:10913761.

Bovine Brucellosis: manual of diagnostic tests and vaccines for terrestrial animals. Geneva: World Organisation for Animal Health; 2009 [cited 2019 Nov 20]. Available from: www.oie.int

Xavier MN, Sant'Anna FM, Silva TMA, Costa EA, Moustacas VS, Merlo FA, Carvalho CA Jr, Dasso MG, Mathias LA, Gouveia AMG, Lage AP, Santos RL. A comparison of two agar gel immunodiffusion methods and a complement fixation test for serologic diagnosis of Brucella ovis infection in experimentally infected rams. Arq Bras Med Vet Zootec. 2011;63(4):1016-21. http://dx.doi.org/10.1590/S010209352011000400031.

Yorinori EH, Pinheiro RR, Gouveia AMG, Nunes MABC, Haddad JPA. Estudo soroepidemiológico da Artrite-Encefalite Caprina e Maedi Visna nas regiões norte e nordeste de Minas Gerais. Rev Cienc Vida. 2003;23:259-60.
Yorinori EH. Características dos sistemas de produção de pequenos ruminantes e prevalências da artrite-encefalite caprina (CAE) e Maedi-Visna (MV) ovina, nas regiões norte e nordeste de Minas Gerais, 2000 [tese]. Belo Horizonte: Universidade Federal de Minas Gerais; 2001.

Zedda MT, Rolesu S, Pau S, Rosati I, Ledda S, Satta G, Patta C, Masala G. Epidemiological study of Toxoplasma gondii infection in ovine breeding. Zoonoses Public Health. 2010;57(7-8):e102-8. http://dx.doi.org/10.1111/j.18632378.2009.01292.x. PMid:19968848.

Zhang B, Bilder C, Biggerstaff B, Schaarschmidt F. binGroup: evaluation and experimental design for binomial group testing. Version 1.0-8. Vienna: R Foundation for Statistical Computing; 2011.

Financial Support: This work was supported by Conselho Nacional de Desenvolvimento Técnico e Científico - CNPq and Fundação de Amparo à Pesquisa do Estado de Minas Gerais - FAPEMIG. 